\title{
KEDUDUKAN HARTA KEKAYAAN DEBITOR YANG DIBEBANKAN HAK TANGGUNGAN TERHADAP PUTUSAN PAILIT
}

\author{
Komang Febrinayanti Dantes \\ Program Studi Ilmu Hukum \\ Jurusan Hukum dan Kewarganegaraan \\ Universitas Pendidikan Ganesha \\ Email : febrinadantes@gmail.com
}

\begin{abstract}
Abstrak
Dalam praktek pada setiap perjanjian kredit yang dibuat oleh bank, bank selalu meminta debitor untuk menyerahkan jaminan. Di dalam Kitab Undang-Undang Hukum Perdata, pada umumnya dikenal dua bentuk jaminan kebendaan yaitu gadai dan hipotik. Permasalahan timbul apabila debitur tidak mampu ataupun tidak mau membayar utangnya kepada kreditur (disebabkan oleh situasi ekonomi yang sulit atau keadaan terpaksa), maka telah disiapkan suatu "pintu darurat" untuk menyelesaikan persoalan tersebut, yaitu dikenal dengan lembaga "kepailitan" dan "penundaan pembayaran". Berdasarkan pasal 1131 dan pasal 1132 Kitab Undang-Undang Hukum Perdata apabila si debitor tidak membayar hutangnya dengan sukarela atau tidak membayarnya walaupun telah ada putusan pengadilan yang menghukum supaya melunasi hutangnya atau karena tidak mampu membayar seluruh hutangnya, maka semua harta bendanya disita untuk dijual dan hasil penjualannya itu dibagi-bagikan di antara semua kreditornya, menurut besar kecilnya piutang dari masing-masing kreditor, kecuali apabila di antara kreditor ada alasan yang sah untuk didahulukan. Undang-Undang Kepailitan (UUK) menentukan bahwa hanya pengadilan yang berwenang menjatuhkan putusan pailit adalah Pengadilan Niaga dengan hakim majelis yang akan bertugas secara khusus.
\end{abstract}

Kata Kunci : Debitor, Hak Tanggungan, Putusan Pailit

\begin{abstract}
In practice in every credit agreement made by the bank, the bank always asks the debtor to submit collateral. In the Civil Code, in general there are two forms of material guarantees namely mortgage and mortgages. Problems arise if the debtor is unable or unwilling to pay his debts to the creditor (caused by a difficult economic situation or forced state), then an "emergency exit" has been prepared to resolve the problem, which is known as the "bankruptcy" and "postponement" .

Based on article 1131 and article 1132 of the Civil Code if the debtor does not pay his debt voluntarily or does not pay it even though there has been a court decision which sentenced him to repay the debt or because he was unable to pay all his debts, all his property was confiscated for sale and proceeds the sale is distributed among all creditors, according to the size of the receivables from each creditor, except if there is a valid reason among creditors to take precedence. The Bankruptcy Act (UUK) stipulates that only the court that has the authority to issue a bankruptcy decision is the Commercial Court with a panel of judges who will be tasked specifically.
\end{abstract}

Keywords: Debtor, Mortgage Rights, Bankruptcy Decision 
Volume 1, Nomor 2 Oktober 2019

ISSN : 2656-9639 (Cetak)

ISSN : 2684-9046 (Online)

\section{Pendahuluan}

Pembangunan ekonomi sebagai bahan dari pembangunan nasional merupakan salah satu upaya untuk mewujudkan kesejahteraan lahir dan bathin bagi seluruh rakyat Indonesia secara adil dan makmur berdasarkan Pancasila dan Undang-Undang Dasar 1945. Semula lembaga hukum kepailitan diatur dalam Undang-Undang tentang Kepailitan dalam Faillissements-verordening Staatsblad 1905:217 juncto Staatblad 1906:348. Karena perkembangan perekonomian dan perdagangan serta pengaruh globalisasi, serta modal yang dimiliki oleh para pengusaha umumnya berupa pinjaman yang berasal dari berbagai sumber, undang-undang tersebut telah menimbulkan banyak kesulitan dalam penyelesaian utang piutang. Penyelesaian utang piutang juga bertambah rumit sejak terjadinya berbagai krisis keuangan yang merembet secara global dan memberikan pengaruh tidak menguntungkan ini telah menimbulkan kesulitan besar terhadap dunia usaha.

Mempelajari perkembangan hukum kepailitan yang berlaku di Indonesia tidak terlepas dari kondisi perekonomian nasional khususnya yang terjadi di Indonesia pada pertengahan tahun 1997. Kondisi perekonomian ini mengakibatkan keterpurukan terhadap pertumbuhan ekonomi yang sebelumnya positif. Seperti yang bisa kita lihat dunia usaha saat ini dimana posisi bidang usaha property pada saat ini ada di level terendah pada perputaran ekonomi di Indonesia, dimana sebelumnya sangat progresif. Hal ini memberikan dampak yang tidak menguntungkan terhadap perekonomian nasional sehingga menimbulkan kesulitan besar terhadap dunia usaha dalam menyelesaikan utang piutang untuk meneruskan kegiatan usaha.
Seiring dengan meningkatnya pembangunan aspek ekonomi tentunya tidak lepas dari faktor pendanaan untuk membiayai suatu aktivitas ekonomi dalam bidang usaha. Dalam rangka meningkatkan pembangunan ekonomi, sangat diperlukan dana dalam jumlah besar. Salah satu sumber pendanaan yang umum dikenal masyarakat yaitu kredit melalui lembaga perbankan sebagai suatu lembaga yang ditunjuk oleh Undang-Undang untuk bertindak sebagai lembaga keuangan yang diperkenankan melakukan penyaluran kredit.

Menurut Undang-Undang Nomor 10 Tahun 1998 tentang Perubahan atas Undang-Undang Nomor 7 Tahun 1992 tentang Perbankan, pada pasal 1 angka 2 disebutkan bahwa "Bank adalah badan usaha yang menghimpun dana dari masyarakat dalam bentuk simpanan dan menyalurkannya kepada masyarakat dalam bentuk kerdit dan/atau bentuk-bentuk lainnya dalam rangka meningkatkan taraf hidup rakyat banyak".

Menurut ketentuan pasal 1 angka 11 Undang-Undang Nomor 10 Tahun 1998 disebutkan bahwa "Kredit adalah penyediaan uang atau tagihan yang dapat dipersamakan dengan itu, berdasarkan persetujuan atau kesepakatan pinjam-meminjam antara bank dengan pihak lain yang mewajibkan pihak peminjam untuk melunasi utangnya setelah jangka waktu tertentu dengan pemberian bunga".

Dalam praktek pada setiap perjanjian kredit yang dibuat oleh bank, bank selalu meminta debitor untuk menyerahkan jaminan. Jaminan merupakan salah satu aspek yang penting dan strategis dalam kaitanya dengan penyaluran kredit, terutama sangat dibutuhkan untuk menekan tingkat risiko atau kemungkinan munculnya kredit bermasalah dalam 
Volume 1, Nomor 2 Oktober 2019

ISSN : 2656-9639 (Cetak)

ISSN : 2684-9046 (Online)

penyaluran kreditnya yang sekaligus sebagai wujud dari penerapan prinsip kehati-hatian.

Adapun yang dimaksud jaminan dalam pemberian kredit menurut pasal 2 ayat (1) Surat Keputusan Direksi Bank Indonesia Nomor 23/69/KEP/DIR tanggal 28 Februari 1991 tentang Jaminan Pemberian Kredit, yaitu keyakinan bank atas kesanggupan debitur untuk melunasi kredit sesuai dengan yang diperjanjikan.

Secara umum jaminan yang banyak digunakan adalah jaminan kebendaan, yaitu jaminan yang mempunyai hubungan langsung dengan benda tertentu, baik barang bergerak maupun barang tidak bergerak, selalu mengikuti benda tersebut ke manapun benda tersebut beralih atau dialihkan, dapat dialihkan dan dapat dipertahankan terhadap siapapun. Misalnya : gadai, hipotik, hak tanggungan atas tanah, fidusia dan sebagainya.

\section{Pembahasan \\ Perjanjian Kredit dengan Jaminan Hak Tanggungan}

Di dalam Kitab Undang-Undang Hukum Perdata, pada umumnya dikenal dua bentuk jaminan kebendaan yaitu gadai dan hipotik. Gadai merupakan jaminan kebendaan bergerak yang dilakukan dengan menyerahkan barang gadai dalam kekuasaan kreditur. Sedangkan jika jaminan itu berbentuk benda tetap, maka sebagai lembaga jaminan dapat dipasang hipotik atau credietverband atau yang sekarang lebih dikenal dengan hak tanggungan.

Undang-Undang Nomor 4 Tahun 1996 tentang Hak Tanggungan Atas Tanah Beserta Benda-Benda Yang Berkaitan Dengan Tanah atau yang lebih dikenal dengan Undang-Undang Hak Tanggungan (UUHT) pada pasal 1 ayat (1) memberikan definisi tentang Hak Tanggungan yaitu sebagai berikut :
"Hak tanggungan atas tanah beserta benda-benda yang terkait dengan tanah, yang selanjutnya disebut Hak Tanggungan, adalah hak jaminan yang dibebankan pada hak atas tanah sebagaimana dimaksud dalam UndangUndang Nomor 5 Tahun 1960 tentang Peraturan Dasar Pokok-Pokok Agraria, berikut atau tidak berikut benda-benda lain yang merupakan satu kesatuan dengan tanah itu, untuk pelunasan utang tertentu yang memberikan kedudukan yang diutamakan kepada kreditor tertentu terhadap kreditor-kreditor lainnya".

Fungsi Hak Tanggungan adalah untuk menjamin utang yang besarnya diperjanjikan dalam perjanjian kredit atau perjanjian utang. Salah satu jaminan kebendaan adalah hak tanggungan dan kreditor yang memegang hak tanggungan merupakan kreditor separatis. Kreditor separatis ini mempunyai preferensi terhadap hak tanggungan yang dipegangnya. Ciri dari preferensi hak tanggungan ini adalah di dalam perjanjian hak tanggungan diperjanjikan bahwa apabila debitur wanprestasi, kreditur dengan kekuasaan sendiri dapat menjual obyek hak tanggungan. Preferensi yang dimiliki oleh pemegang hak tanggungan ini merupakan perwujudan dari asas yang dikenal dalam hukum jaminan yaitu asas "droit de preference"

Kreditor separatis adalah kreditor pemegang hak jaminan kebendaan, yang dapat bertindak sendiri. Golongan kreditor ini tidak terkena akibat putusan pernyataan pailit, artinya hak-hak eksekusi mereka tetap dapat dijalankan seperti tidak ada kepailitan debitor. Kreditor separatis pada dasarnya memiliki kedudukan yang lebih aman jika dibandingkan dengan kreditor lainnya. Karena, ketika debitor melakukan wanprestasi, kreditor separatis dapat langsung melakukan 
Volume 1, Nomor 2 Oktober 2019

ISSN : 2656-9639 (Cetak)

ISSN : 2684-9046 (Online)

eksekusi atas jaminan yang dimilikinya. Namun kreditor separatis pun dapat menangguhkan haknya untuk melakukan eksekusi atas jaminan yang dimilikinya, dengan mengajukan Permohonan Penundaan Kewajiban Pembayaran Utang (PKPU) terhadap debitor yang bersangkutan. Dengan tujuan lebih memberikan "tekanan" kepada debitor yang bersangkutan, agar mau bernegosiasi dengan lebih serius dalam menyelesaikan kewajibannya. Namun Undang-Undang Nomor 37 tahun 2004 tentang Kepailitan dan Penundaan Kewajiban Pembayaran Utang (UUK) tidak mengatur demikian. UU Kepailitan memberikan kesempatan yang sama bagi seluruh jenis kreditor untuk mengajukan permohonan PKPU terhadap debitor.

Sebagaimana ketentuan dalam Pasal 222 ayat (3) UU Kepailitan, yaitu :"Kreditor yang memperkirakan bahwa Debitor tidak dapat melanjutkan membayar utangnya yang sudah jatuh waktu dan dapat ditagih, dapat memohon agar kepada Debitor diberi penundaan kewajiban pembayaran utang, untuk memungkinkan Debitor mengajukan rencana perdamaian yang meliputi tawaran pembayaran sebagian atau sekuruh utang kepada kreditornya."

\section{Debitur Cidera Janji dalam Perjanjian Kredit}

Didalam praktek hukum, adakalanya seorang yang berhutang (debitur) lalai memenuhi kewajibannya (prestasinya). Keadaan yang demikian disebut dengan wanprestasi atau kelalaian atau tidak melakukan pemenuhan dalam perjanjian ataupun melakukan prestasi tetapi tidak dilaksanakan tepat pada waktunya dan tidak sesuai dengan apa yang seharusnya.
Permasalahan timbul apabila terdapat beberapa kreditur satu atau lebih dan ternyata debitur cidera janji terhadap salah satu kreditur atau beberapa kreditur itu, atau debitur jatuh pailit dan harta kekayaannya harus dilikuidasi. Sudah barang tentu masingmasing kreditur merasa mempunyai hak terhadap harta kekayaan debitur itu sebagai jaminan piutangnya masingmasing.

\section{Putusan Pailit Terhadap Jaminan Hak Tanggungan}

Kepailitan dengan merujuk kepada ketentuan-ketentuan yang diatur dalam Pasal 1 ayat (1) Undang-Undang Nomor 37 Tahun 2004 tentang Kepailitan dan Penundaan Kewajiban Pembayaran Utang (UUK) adalah :"sita umum atas semua kekayaan debitor pailit yang pengurusan dan pemberesannya dilakukan oleh Kurator di bawah pengawasan Hakim Pengawas sebagaimana diatur dalam UndangUndang ini." Kepailitan adalah suatu kondisi dimana debitor tidak lagi berwenang atas harta-hartanya selama proses kepailitan berlangsung dikarenakan kewenangannya beralih kepada Kurator.

Didalam dunia perniagaan, apabila debitur tidak mampu ataupun tidak mau membayar utangnya kepada kreditur (disebabkan oleh situasi ekonomi yang sulit atau keadaan terpaksa), maka telah disiapkan suatu "pintu darurat" untuk menyelesaikan persoalan tersebut, yaitu dikenal dengan lembaga "kepailitan" dan "penundaan pembayaran". Lembaga kepailitan mempunyai fungsi yang sangat penting, yaitu dengan kepailitan akan diadakan suatu penyitaan umum (eksekusi) terhadap seluruh harta kekayaan debitur, yang selanjutnya nanti akan dibagi kepada para kreditur secara seimbang dan adil 
Volume 1, Nomor 2 Oktober 2019

ISSN : 2656-9639 (Cetak)

ISSN : 2684-9046 (Online)

di bawah pengawasan petugas yang berwenang untuk itu.

Secara itimologi istilah kepailitan berasal dari kata pailit. Selanjutnya istilah "pailit" berasal dari kata Belanda failliet yang mempunyai arti ganda yaitu sebagai kata benda dan sebagai kata sifat. Istilah failliet sendiri berasal dari Perancis yaitu faillite yang berarti pemogokan atau kemacetan pembayaran, sedangkan orang yang mogok atau berhenti membayar dalam bahasa bahasa Perancis disebut Le faili. Kata kerja failir artinya adalah gagal. Sedangkan dalam bahasa Inggris dikenal dengan kata to fail dengan arti yang sama, dan dalam bahasa Latin disebut failure.

Kepailitan merupakan suatu lembaga hukum perdata eropa, sebagai realisasi dari dua asas pokok yang terkandung dalam pasal 1131 dan 1132 Kitab Undang-Undang Hukum Perdata. Dalam Pasal 1131 Kitab UndangUndang Hukum Perdata menyatakan bahwa : Segala kebendaan si berutang, baik yang bergerak maupun yang tak bergerak, baik yang sudah ada maupun yang baru aka nada di kemudian hari menjadi tanggungan untuk segala perikatan perseorangan".

Selanjutnya dalam Pasal 1332 Kitab Undang-Undang Hukum Perdata dinyatakan pula bahwa : "Kebendaan tersebut menjadi jaminan bersama-sama bagi semua orang yang mengutangkan padanya; pendapatan penjualan bendabenda itu dibagi-bagi menurut keseimbangan, yaitu menurut besarkecilnya piutang masing-masing, kecuali apabila di antara para berpiutang itu ada alas an-alasan yang sah untuk didahulukan."

Melihat isi kedua pasal tersebut diatas, terkandung asas; apabila si debitor tidak membayar hutangnya dengan sukarela atau tidak membayarnya walaupun telah ada putusan pengadilan yang menghukum supaya melunasi hutangnya atau karena tidak mampu membayar seluruh hutangnya, maka semua harta bendanya disita untuk dijual dan hasil penjualannya itu dibagi-bagikan di antara semua kreditornya, menurut besar kecilnya piutang dari masingmasing kreditor, kecuali apabila di antara kreditor ada alasan yang sah untuk didahulukan.

Undang-Undang Kepailitan (UUK) menentukan bahwa hanya pengadilan yang berwenang menjatuhkan putusan pailit adalah Pengadilan Niaga dengan hakim majelis yang akan bertugas secara khusus. Pembentukan Pengadilan Niaga ini merupakan langkah diferensiasi atas peradilan umum yang dimungkinkan pembentukannya berdasarkan Undang-Undang Nomor 14 Tahun 1970 Tentang Pokok-Pokok Kekuasaan Kehakiman, yang sekarang telah diganti dengan Undang-Undang Nomor 4 Tahun 2004 tentang Kekuasaan Kehakiman. Sebagai langkah awal dari pemeriksaan kepailitan dapat didahului dengan adanya "permohonan kepailitan" oleh pihak yang berwenang. Menurut Undang-Undang Kepailitan Nomor 37 Tahun 2004 (pasal 2), maka yang dapat menjadi pemohon dalam suatu perkara pailit adalah salah satu dari pihak-pihak berikut :

1. Pihak debitor itu sendiri;

2. Salah satu atau lebih dari pihak kreditor;

3. Pihak Kejaksaan jika menyangkut dengan kepentingan umum;

4. Pihak Bank Indonesia jika debitornya adalah suatu bank;

5. Pihak Badan Pengawas Pasar Modal jika debitornya adalah Perusahaan Efek, Bursa Efek, Lembaga Kliring dan 
Penjaminan, maupun Lembaga Penyimpanan dan Penyelesaian;

6. Pihak Menteri Keuangan jika debitornya adalah Perusahaan Asuransi, Perusahaan Reasuransi, Dana pension, atau Badan Usaha Milik Negara yang bergerak di bidang kepentingan publik.

Sedangkan yang dapat dinyatakan pailit (termohon), menurut Ahmad Yani dan Gunawan Widjaja adalah:

1. "Orang perorangan", baik lakilaki maupun perempuan, yang telah menikah maupun belum menikah. Jika permohonan pernyataan pailit tersebut diajukan oleh "debitor perorangan yang telah menikah", maka permohonan tersebut hanya dapat diajukan atas persetujuan suami atau isterinya, kecuali antara suamiisteri tersebut tidak ada percampuran harta;

2. "Perserikatan-perserikatan dan perkumpulan-perkumpulan tidak berbadan hukum lainnya". Permohonan pernyataan pailit terhadap suatu "firma" harus memuat nama dan tempat kediaman masing-masing persero yang secara tanggung renteng terikat untuk seluruh utang firma;

3. "Perseroan-perseroan, perkumpulan-perkumpulan, koperasi maupun yayasan yang berbadan hukum". Dalam hal ini berlakulah ketentuan mengenai kewenangan masingmasing badan hukum sebagaimana diatur dalam Anggaran Dasarnya;

4. "Harta Peninggalan".

Permohonan pernyataan pailit diajukan kepada Ketua Pengadilan (pasal 6) yang daerah hukumnya meliputi daerah tempat kedudukan hukum debitor(pasal 3 ayat (1). Dalam Undang-Undang Nomor 37 Tahun 2004 Pasal 7 menegaskan bahwa pemohonan kepailitan harus diajukan oleh seorang Advokat. Diharuskannya menggunakan tenaga advokat tentunya bertujuan agar proses persidangan berjalan dengan cepat dan fair dibandingkan dengan mereka yang bukan sarjana hukum. Didalam sistem Anglo Saxon, perihal permohonan kepailitan ditentukan, bahwa permohonan kepailitan haruslah diajukan secara tertulis. Hal ini terbukti dengan digunakannya istilah "Petition".

\section{Penutup}

Krisis global membuat hutang menjadi membengkak luar biasa sehingga mengakibatkan banyak sekali debitor yang tidak mampu membayar utang-utangnya. Di samping itu kredit macet di perbangkan dalam negeri juga semakin membumbung tinggi secara luar biasa. Dirasakan bahwa peraturan kepailitan yang ada tidak dapat diandalkan. Banyak debitor yang dihubungi oleh kreditornya karena berusaha mengelak untuk memenuhi tanggungjawab terhadap kewajiban yang harus dilakukan atas penyelesaian utang-utangnya. Sedangkan restrukturisasi utang hanyalah memungkinkan ditempuh apabila debitor bertemu dan duduk berunding, bisnis debitor harus masih memiliki prospek yang baik untuk mendatangkan revenue sebagai sumber pelunasan utang yang direstrukturisasikan itu. Dengan demikian diharapkan adanya feedback antara kreditor dan debitor dengan baik, sehingga dirasakan dapat menguntungkan kedua belah pihak.

\section{Daftar Pustaka}

\section{Buku :}

Ahmad Yani dan Gunawan Widjaja, Seri Hukum Bisnis (Kepailitan), 
Volume 1, Nomor 2 Oktober 2019

ISSN : 2656-9639 (Cetak)

ISSN : 2684-9046 (Online)

Raja Grafindo Persada, Jakarta, 2002.

Djumhana, Muhammad, Hukum Perbangkan di Indonesia, Citra Aditya Bakti, Bandung, 2003.

Sutarno, Aspek-Aspek Hukum Perkreditan pada Bank, Alfabeta, Bandung, 2004.

Victor M. Situmorang dan Hendri Soekarso, Pengantar Hukum Kepailitan di Indonesia, Rineka Cipta, Jakarta, 1994.

Zainal Asikin, Hukum Kepailitan dan Penundaan Pembayaran di Indonesia, Raja Grafindo Persada, Jakarta, 2001.

Jono, S.H., Hukum Kepailitan, Sinar Grafika, Jakarta, 2010.

Peraturan Perundang-Undangan :

Burgerlijk Wetboek diindonesiakan oleh Subekti dan Tjitrosudibio, Kitab Undang-Undang Hukum Perdata, Pradnya Paramita, 2002.

Indonesia, Undang-Undang Nomor 37 Tahun 2004 Lembaran Negara Republik Indonesia Tahun 2004 Nomor 131, tentang Kepailitan dan Penundaan Kewajiban Pembayaran Utang.

Indonesia, Undang-Undang Nomor 10 Tahun 1998 Lembaran Negara Republik Indonesia Tahun 1998 Nomor 182, tentang Perubahan atas Undang-Undang Nomor 7 Tahun 1997 tentang Perbankan.

Indonesia, Undang-Undang Nomor 4 Tahun 1996 Lembaran Negara Republik Indonesia Tahun 1996 Nomor 42, tentang Hak Tanggungan atas Tanah Beserta Benda-Benda yang Berkaitan dengan Tanah.

Indonesia, Undang-Undang Nomor 5 Tahun 1960 Lembaran Negara Republik Indonesia Tahun 1960 Nomor 104, tentang Peraturan Dasar Pokok-Pokok Agraria. 